Pesq. Vet. Bras. 36(1):13-18, janeiro 2016 DOI: $10.1590 / \mathrm{S} 0100-736 \mathrm{X} 2016000100002$

\title{
Histologic and inflammatory lamellar changes in horses with oligofructose-induced laminitis treated with a CXCR1/2 antagonist ${ }^{1}$
}

\author{
Leonardo R. de Lima², Heloisa M.F. Mendes², Frederico M. Soriani ${ }^{3}$, Danielle G. de \\ Souza $^{2}$, Geraldo Eleno S. Alves ${ }^{2}$, Mauro M. Teixeira ${ }^{3}$ and Rafael R. Faleiros ${ }^{2 *}$
}

\begin{abstract}
Lima L.R., Mendes H.M.F., Soriani F.M., Souza D.G., Alves G.E.S., Teixeira M.M. \& Faleiros R.R. 2016. Histologic and inflammatory lamellar changes in horses with oligofructose-induced laminitis treated with a CXCR1/2 antagonist. Pesquisa Veterinária Brasileira 36(1):13-18. Escola de Veterinária, Universidade Federal de Minas Gerais, Av. Antônio Carlos 6627, Belo Horizonte, MG 30161-970, Brazil. E-mail: faleirosufmg@gmail.com

With the hypothesis that blocking chemokine signaling can ameliorate acute laminitis, the aim was to evaluate the therapeutic effect of intravenous DF1681B, a selective antagonist for CXCR1 and CXCR2 (chemokine receptors), in an oligofructose equine laminitis model. To twelve mixed breed clinically healthy hoses with no previous history of hoof-related lameness was administered oligofructose $(10 \mathrm{~g} / \mathrm{kg}$ given by nasogastric tube $)$ and divided into two groups: treated (intravenous DF1681B at $30 \mathrm{mg} / \mathrm{kg} 6,12,18$, and $24 \mathrm{~h}$ after oligofructose) and non-treated groups. Laminar biopsies were performed before and 12, 36, and $72 \mathrm{~h}$ after administering oligofructose. Samples were stained with periodic acid-Schiff (PAS) and scored from 0 to 6 according to epidermal cell and basal membrane changes. The IL-1 $\beta$, IL-6, and CXCL1 RNA expressions were determined by RT-PCR. Parametric and non-parametric tests were used to compare times within each group $(\mathrm{P}<0.05)$. The PAS grades and IL-1 $\beta$ and IL- 6 RNA expression increased in the non-treated group, but remained constant in the treated horses. In conclusion, DF1681B therapy reduced laminar inflammation and epidermal deterioration in treated horses. CXCR1/2 blockage should be considered therapeutically for equine acute laminitis.
\end{abstract}

INDEX TERMS: Neutrophil, chemokine, CXC receptors, horse, laminitis.

RESUMO.- [Alterações histológicas e inflamatórias no tecido laminar de equinos submetidos ao modelo de laminite por oligofrutose e tratados com um antagonista para CXCR1/2.] A expressão de quimiocinas e a infiltração de leucócitos no tecido laminar são característicos de laminite aguda de equinos. 0 presente estudo avaliou o efeito terapêutico da administração intravenosa de DF1681B , um antagonista seletivo para CXCR1 e CXCR2 (receptores de quimiocinas), em um modelo de laminite equina por oligofrutose. Utilizaram-se doze cavalos sem raça definida, compreendendo quatro machos e oito fêmeas não gestantes,

\footnotetext{
${ }^{1}$ Received on June 1,2015

Accepted for publication on October 27, 2015.

${ }^{2}$ Escola de Veterinária, Universidade Federal de Minas Gerais (UFMG), Av. Antônio Carlos 6627, Belo Horizonte, MG 30161-970, Brazil.

${ }^{3}$ Instituto de Ciências Biológicas (ICB), UFMG, Av. Antônio Carlos 6627, Cx. Postal 486, Pampulha, Belo Horizonte, MG 31270-901. ${ }^{*}$ Corresponding author: faleirosufmg@gmail.com
}

com idade (média \pm SD) $7 \pm 3,5$ anos, pesando $305 \pm 35 \mathrm{~kg}$ e com uma pontuação média de condição corporal de $5 \pm 1 / 9$. Os indivíduos elegíveis eram clinicamente saudáveis, sem história prévia de claudicação relacionados ao casco. Após administração de oligofrutose $(10 \mathrm{~g} / \mathrm{kg}$ por sonda nasogástrica), os animais foram divididos em dois grupos: tratado (30 mg/kg de DF1681B intravenosa, 6, 12, 18 e 24h após a oligofrutose) e não tratado, que recebeu placebo. Biópsias laminares foram realizadas antes e 12, 36 e 72h após a administração de oligofrutose. As amostras foram coradas com ácido periódico de Schiff (PAS) e classificadas de 0-6 de acordo com alterações nas células epidérmicas e na membrana basal. Também determinaram-se as expressões gênicas de IL-1 $\beta$, CXCL1 e IL-6 por RT-PCR. Testes paramétricos e não paramétricos foram utilizados para comparar os momentos em cada grupo $(\mathrm{P}<0,05)$. Estatisticamente, os graus PAS e as expressões de IL-1 $\beta$ e IL-6 se elevaram após a indução no grupo não tratado, mas se mantiveram cons- 
tantes nos cavalos tratados. Em conclusão, a terapia por DF1681B reduziu a inflamação laminar e a deterioração epidérmica em equinos submetidos ao modelo de intoxicação por oligofructose. 0 bloqueio de receptores CXCR1/2 deve ser considerado como uma opção terapêutica para prevenção da laminite aguda de equinos.

TERMOS DE INDEXAÇÃO: Neutrófilos, quimiocinas, receptores CXC, cavalo, laminite.

\section{INTRODUCTION}

The equine hoof is extremely resistant to the demanding external environment; however, the destruction of its microstructure by laminitis has catastrophic consequences for the welfare and even survival of the affected horse. The damaged dermal-epidermal junction destroys adherence between the hoof and distal phalanx, preventing weight bearing and locomotion. A strong correlation between microstructural damage and the severity of clinical signs was established (Pollitt 1996).

Dermal-epidermal junction collapse is common in laminitis of numerous etiologies, but the initial event triggering the structural failure remains poorly understood (Katz \& Bailey 2012). Multiple studies propose resident leukocyte activation in the lamella and leukocytic infiltration from the bloodstream, associated with systemic inflammatory response syndrome (SIRS), as probable mechanisms that initiate structural failure (Black et al. 2006, Hurley et al. 2006, Belknap et al. 2007, Loftus et al. 2007, Stewart et al. 2009, Faleiros et al. 2009b, Faleiros et al. 2011a). Increased pro-inflammatory cytokine expression (mainly IL-1 $\beta$ and IL-6), as well as CXC and CCR chemokines, during the developmental stage, indicates that these molecules may play an important role in leukocyte migration in the early events of laminitis (Belknap et al. 2007, Faleiros et al. 2009a, Leise et al. 2011, Faleiros et al. 2011b, Visser et al. 2011).

CXCR1 and CXCR2 are G protein receptors and have a high affinity for chemokines that are glutamine-leucine-arginine positive (Mukaida 2003, Kim et al. 2011). These chemokines have been detected in several human and equine tissues affected by inflammatory conditions associated with severe neutrophil infiltration (Franchini et al. 2000, Giustizieri et al. 2001, Ainsworth et al. 2006, Woodman et al. 2006). Selective pharmacologic blockade of CXCR $1 / 2$ is a promising strategy for controlling inflammation and could potentially treat and prevent equine laminitis (Bizzarri et al. 2006, Coelho et al. 2008).

DF1681B is a CXCR1/2 noncompetitive, allosteric antagonist and potentially inhibits a variety of chemokine-induced biological activities (Souza et al. 2004, Bizzarri et al. 2006, Gorio et al. 2007, Zarbock et al. 2008, Marsh et al. 2011). DF1681B reduced secondary spinal cord degeneration in a rat model of trauma, as well as reduced oligodendrocyte apoptosis and neutrophil infiltration of ED-2 positive cells. In addition, the recovery rate for hind limb movement was higher in treated animals (Gorio et al. 2007). In another study, DF1681B inhibited neutrophil adhesion to synovial endothelium, reducing neutrophilic recruitment into the synovial membrane, and alleviating tissue damage in a rat model of arthritis (Coelho et al. 2008). DF1681B was also shown to reduce ischemic and intestinal reperfusion injury in mice by decreasing vascular permeability and neutrophil influx (Souza et al. 2004).

Despite recent evidence indicating leukocyte involvement in laminitis development (Black et al. 2006, Hurley et al. 2006, Belknap et al. 2007, Loftus et al. 2007, Stewart et al. 2009, Faleiros et al. 2009b, Faleiros et al. 2011a), and the therapeutic potential of DF1681B for neutrophil migration in rodents, this drug has not yet been studied in horses.

The present study evaluated the effect of DF1681B, a CXCR1/2 antagonist, on histological lesions, and the IL-1 $\beta$, IL-6, and CXCL1 expressions in equine lamellar tissue following oligofructose-induced laminitis.

\section{MATERIALS AND METHODS}

Twelve mixed breed horses, comprising four castrated males and eight non-pregnant females, aged (mean \pm SD) $7 \pm 3.5$ years, weighing $305 \pm 35 \mathrm{~kg}$, and with a mean body condition score of $5 \pm 1 / 9$ were evaluated. Horses were considered clinically normal based on physical and hematological exams and had no previous history of hoof-related lameness. After a 2-week adaptation period of consuming only grass hay (Cynodum $\mathrm{sp}$.), the horses were randomly divided into two groups: treated $(n=6)$ and non-treated $(n=6)$. This protocol was approved by the Ethics Committee on Animal Use and Experimentation of UFMG (CEUA /UFMG 225/2009).

To induce laminitis, all horses were administered $10 \mathrm{~g} / \mathrm{kg}$ of oligofructose (Raftilose P95, Embrafarma Pharmaceutical Expertise, São Paulo/SP, Brazil) diluted in 3L of water through a nasogastric tube. At $6,12,18$, and $24 \mathrm{~h}$ after oligofructose administration, horses in the treated group received DF1681B (Dompé Pharma SpA Research Center, L'Aquila, Italy), intravenously, at $30 \mathrm{mg} / \mathrm{kg}$ diluted in $500 \mathrm{~mL}$ of sterile $0.9 \%$ saline. The solution was filtered through a $0.22 \mu \mathrm{m}$ bacteriological filter (Biofil syringe filter, Jet Bio-Filtration Products Co., Guangzhou, China) before administration.

Before (T0) and 12, 36, and 72h after oligofructose administration, biopsies were taken sequentially from the left pelvic (T0), right pelvic (T12), right thoracic (T36), and left thoracic (T72) hooves of each horse. The horses were sedated with $10 \%$ xylazine (1mg/kg intravenously), and perineural anesthesia $(5 \mathrm{~mL}$ of $2 \%$ lidocaine at each branch of the palmar or plantar nerve) was administered at the abaxial surface of the proximal sesamoid bones in each hoof. At each biopsy site, three unaligned holes were generated across the dorsal hoof wall. Using aseptic technique, an $8 \mathrm{~mm}$ drill mounted in an electric driller was used to remove the hoof wall until the white soft tissue preceding the lamella was reached. The drill bit was then replaced with a $6 \mathrm{~mm}$ diameter Keyes dermal punch (Keyes dermal punch, ABC Instrumentos Cirúrgicos, São Paulo/SP, Brazil), which was advanced under high rotation until contacting the dorsal distal phalanx surface (Fig.1). Hemorrhage was controlled with sterile gauze until ceasing, and the site was sealed with polymethyl methacrylate.

Samples were divided in half and immediately immersed into $10 \%$ buffered formalin, or frozen using liquid nitrogen. After $48 \mathrm{~h}$, the formalin-fixed samples were processed routinely and embedded in paraffin. Frozen samples were stored at $-80^{\circ} \mathrm{C}$ for molecular analysis.

For histologic analysis, the paraffin-embedded $5 \mu \mathrm{m}$ tissue sections were stained with periodic acid-Schiff (PAS). The sections were scored using a histological grading system for assessing lamellar degradation (Faleiros et al. 2011a). All sections were scored by an investigator blinded to the collection times and treatment groups. 


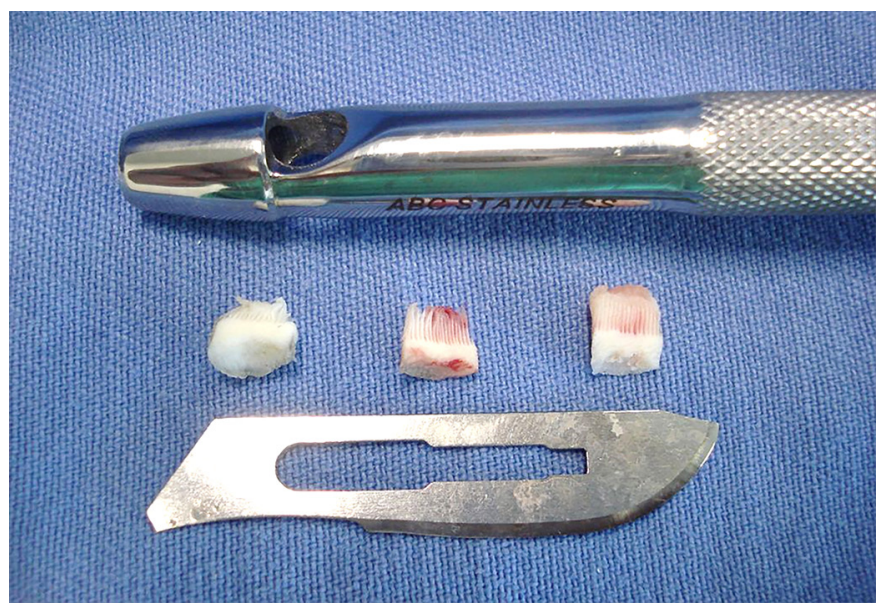

Fig.1. Hoof lamellar samples taken from biopsy procedure technique using a Keyes dermal punch.

Frozen samples were thawed in Petri dishes. The deep dermis was already lost during biopsy; the excess stratum corneum was removed with a scalpel. RNA was extracted, beginning by adding trizol (Invitrogen, Carlsbad, CA, USA) at $1 \mathrm{~mL} / 100 \mathrm{mg}$ of tissue, followed by adding chloroform; the samples were then homogenized and vortexed. The samples were centrifuged at $12,000 \mathrm{rpm}$, for $10 \mathrm{~min}$ at $4^{\circ} \mathrm{C}$. Between samples, the homogenizer was rinsed using $50 \mathrm{~mL}$ Falcon tubes containing distilled water, followed by $70 \%$ isopropanol, then distilled water again.

After centrifugation, the aqueous phase containing RNA was transferred into new microfuge tubes containing $500 \mu \mathrm{L}$ of isopropanol. The sample was centrifuged again at 12,000rpm, for 10 min, at $4{ }^{\circ} \mathrm{C}$, generating an RNA pellet. The supernatant was discarded, and $150 \mu \mathrm{L}$ of $70 \%$ ethanol in DEPC (diethyl pyrocarbonate) was slowly added to the RNA pellet. The sample was once more centrifuged at $12,000 \mathrm{rpm}$ and $4^{\circ} \mathrm{C}$ for $10 \mathrm{~min}$. The $70 \%$ ethanol was carefully discarded to avoid disturbing the RNA pellet. The microtubes were stored open on a sheet of paper to dry the pellet.

After resuspension and spectrophotometeric quantification, the RNA was converted into cDNA by adding oligodT ( $50 \mathrm{mmol} / \mathrm{L}$ ) to the RNA sample, which was then heated to $70^{\circ} \mathrm{C}$ for $5 \mathrm{~min}$ and abruptly cooled on ice. The cDNA was generated using $1 \mu \mathrm{L}$ of dNTP $(10 \mathrm{mmol} / \mathrm{L}), 1 \mu \mathrm{L}$ of DTT $(1 \mathrm{M}), 4 \mu \mathrm{L}$ of SuperScript Buffer $(5 \times)$, and $1 \mu \mathrm{L}$ of RNAse (SuperScript III Reverse Transcriptase, Invitrogen, Carlsbad, CA, USA); the mixture was subjected to a thermal cycler for $90 \mathrm{~min}$ followed by $15 \mathrm{~min}$ at $75^{\circ} \mathrm{C}$.

The primer sequences are described in Table 1 . The scale synthesis was $25 \mathrm{nmol}$, desalted, and the prepared primers were diluted to $5 \mu \mathrm{mol} / \mathrm{L}$. The real-time PCR was performed using $5 \mu \mathrm{L}$ of SYBR Green PCR Master Mix (SYBR Green PCR Master Mix, Ap-
Table 1. cDNA primer sequences used for real-time PCR

\begin{tabular}{lcc}
\hline Gene & Direction & \multicolumn{1}{c}{ Sequence } \\
\hline$\beta$-actin & Forward & 5'-TTCCCTGGAGAAGAGCTACGA-3' \\
$\beta$-actin & Reverse & 5'-TTTCGTGGATGCCACAGGAT-3' \\
IL-1 $\beta$ & Forward & 5'-GCTGCCTTCCCTATATTAGTGC-3' \\
IL-1 $\beta$ & Reverse & 5'-AGTGAGTAGCAGAGGTGAGAG-3' \\
IL-6 & Forward & 5'-TCTTCACAAGCACCGTCACT-3' \\
IL-6 & Reverse & 5'-GTGGGGAAAGCAGTAGCCAT-3' \\
CXCL-1 & Forward & 5'-TCTCAATCCTGAAGCCCCA-3' \\
CXCL-1 & Reverse & 5'-GCCAACAGCAACCAGTACAC-3'
\end{tabular}

plied Biosystems, Grand Island, NY, USA), $1 \mu \mathrm{L}$ of forward primer, $1 \mu \mathrm{L}$ of reverse primer, and $1 \mu \mathrm{L}$ of ultrapure water with a real-time PCR device (7500 Fast Real Time PCR, Applied Biosystems, Grand Island, NY, USA). The results were analyzed using the $2 \Delta \Delta \mathrm{Ct}$ method. This processing involves identifying and removing outlying individuals whose assay results exhibit marked, and likely artifactual, deviation from the other assay results (Chow et al. 2012).

Data were analyzed with statistical software (Prism 5, GraphPad Software, Inc., La Jolla, CA, USA). The histologic data were compared within each group over time using the Mann-Whitney test. PCR data were compared within each group over time using the one-way ANOVA followed by the Newman-Keuls test. Significance was designated at $\mathrm{P}<0.05$ for all tests.

\section{RESULTS}

The biopsy procedure was well tolerated by the subjects with no major complications observed. There was intense hemorrhage at the biopsy site immediately upon removing the sample, but this ceased with manual compression. The skin punch biopsy coupled to the drill produced appropriate samples to study the lamellar epidermis and dermal-epidermal junction. However, most of the sublamellar dermis (deep dermis) was lost during biopsy.
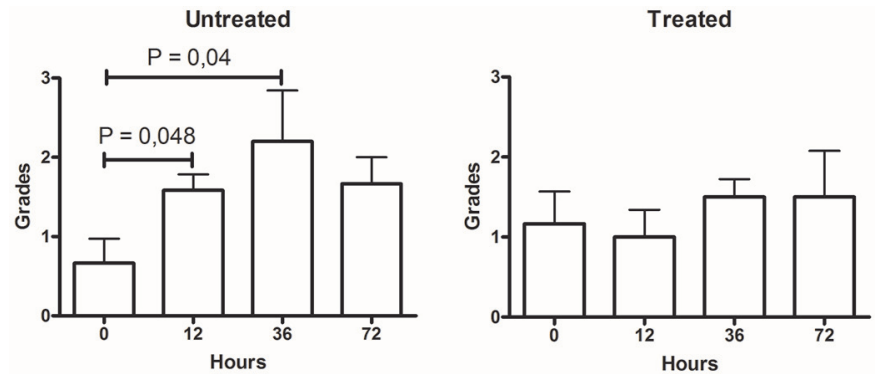

Fig.2. Mean ( \pm SE) lamellar tissue PAS grades before $(0)$ and after $(12,36$, and $72 \mathrm{~h}$ ) laminitis induction (oligofructose model) in horses treated or not with DF1681B.

\section{IL-1 $\beta$}

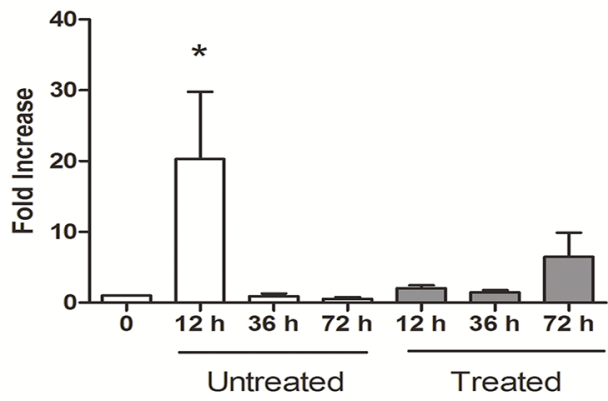

IL-6

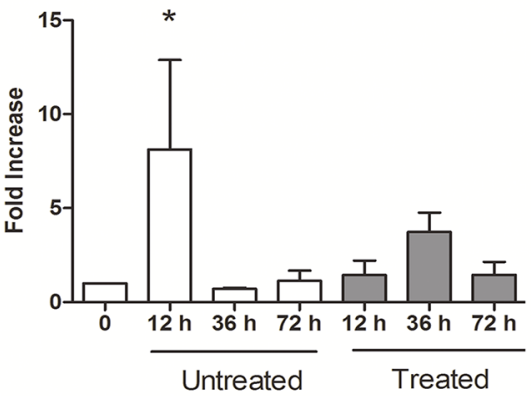

CXCL1

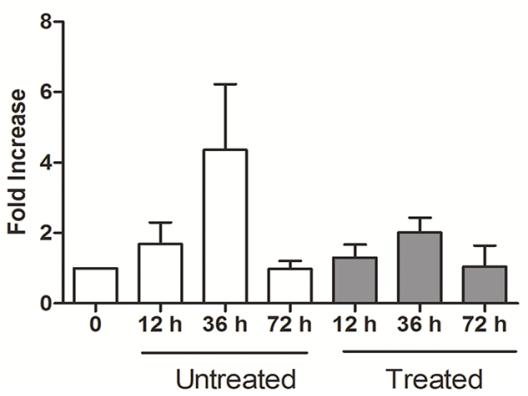

Fig.3. Mean $( \pm$ SE) fold increase change in IL-1 $\beta$, IL-6, and CXCL1 RNA expression in lamellar tissue before (0) and after $(12,36$, and $72 \mathrm{~h})$ laminitis induction (oligofructose model) in horses treated or not with DF1681B. 
On histologic analysis, most samples in the untreated group were graded between 2 and 3 after oligofructose administration, and the increase from basal values was statistically significant at 24 and $36 \mathrm{~h}$. By contrast, lamellar sections in the treated group were graded between 1 and 2, which was not a significant change (Fig.2).

The pro-inflammatory chemokine mRNA expression was significantly increased in the untreated group alone (Fig.3). Twelve hours after oligofructose administration, IL-1 $\beta$ expression increased 20 -fold $(\mathrm{P}=0.0016)$ and the IL-6 expression increased 8-fold $(\mathrm{P}=0.03)$ in the untreated group. The CXCL1 expression peaked at $36 \mathrm{~h}$ in the untreated group, however, this change was not statistically significant $(\mathrm{P}=0.16)$ compared to baseline.

\section{DISCUSSION}

This is the first known study evaluating a CXCR1/2 receptor antagonist in horses. Based on reported DF1681B benefits in decreasing neutrophilic tissue damage in rodent models of spinal trauma (Gorio et al. 2007), intestinal ischemia and reperfusion (Souza et al. 2004), acute lung injury (Zarbock et al. 2008), and antigen-induced arthritis (Rabbit et al. 2008), we examined its possible therapeutic effects on equine laminitis. The lack of both a PAS grade increase and an IL-1 $\beta$ and IL- 6 increase at $12 \mathrm{~h}$ in the treated group suggests that DF1681B mitigates the inflammatory damage in the lamellar tissue in oligofructose-induced equine laminitis. Though promising, these findings are preliminary, and our model has several notable limitations.

Most studies using an equine laminitis model performed euthanasia to obtain the lamellar samples (French et al. 2004, Hurley et al 2006, Van Eps et al. 2006, Belknap et al. 2007). This methodology is advantageous because numerous hoof lamellae, other tissues, and organ samples are available for each horse. However, a large number of horses are necessary to evaluate the evolution of lesions over time because each time point demands its own experimental group. This method increases the cost and hampers new drug development. To minimize animal usage and evaluate DF1681B, a new anti-inflammatory drug already assessed in human clinical trials, biopsy was used to harvest lamellar tissues.

Biopsies were taken from all feet of each horse based on a recent study demonstrating that histologic lesions develop evenly across all four hooves in experimentally induced laminitis (Leise et al. 2012). Feet were biopsied sequentially, and the forefeet were biopsied at the later time points (36 and $72 \mathrm{~h}$ ) because they are more prone to developing laminitis lesions. A prior study revealed significant variability in the carbohydrate overload-induced laminitis lesions between samples obtained from a single hoof (Faleiros et al. 2011a); therefore, three samples were taken from each hoof.

Biopsy has been used to histologically evaluate equine lamella by other authors (Hanly et al. 2009, Paes Leme et al. 2010, Visser \& Pollitt 2011, Gravena et al. 2012), including serial collection (Hanly et al. 2009, Visser \& Pollitt 2011). In the present study, a new hoof biopsy technique was used. Attaching a skin biopsy punch device to a drill provided a quick and easy way to obtain lamellar tissue samples. However, the sublamellar (deep) dermis was lost in most samples during collection, which limits the histologic investigation to the lamellar stratrum.

Histologic signs of laminitis were found in all horses in the untreated group after oligofructose administration. However, the epidermis and basement membrane PAS grades were consistently low (2 to 3 ) compared to other studies of carbohydrate overload models (Faleiros et al. 2011a, Visser \& Pollitt 2011). van Eps \& Pollitt (2006) reported extensive epidermal cell detachment from the basement membrane (corresponding to score 5) $48 \mathrm{~h}$ after administering the same oligofructose dose. Similarly, in a cornstarch model using the same PAS grade system, PAS scores between 3 and 4 occurred in $50 \%$ of subjects between 20 and $48 \mathrm{~h}$ (Faleiros et al. 2011a).

However, the histologically mild laminitis is consistent with another study reporting mild clinical signs of laminitis in these same horses (Lima et al. 2013). Several factors may underlie the lower severity of inflammation found in this study compared to others (van Eps \& Pollitt 2006, Faleiros et al. 2011a). However, the low body weight of these horses appears to be the primary cause. A limited amount of DF1681B was available for this study, therefore we elected to use relatively small horses. There are reports of absent to mild clinical signs in light weight horses with oligofructose-induced laminitis (van Eps, personnal communication 2012).

Another factor potentially causing the mild clinical and lamellar inflammation in the present model is the intense hemorrhage following biopsy. Oligofructose is believed to disturb the equine large intestinal microenvironment, causing systemic absorption of pathogen-associated molecular patterns (PAMPs) produced by atypical lactic fermentation and damage-associated molecular patterns (DAMPs) originating from the damaged intestine; both can trigger lamellar inflammation (Milinovich et al. 2006, 2010, Belknap et al. 2010. Hemorrhage at the biopsied sites beginning $6 \mathrm{~h}$ after oligofructose administration may deplete the PAMPs and DAMPs mitigating the initial lamellar inflammation. Notably, hemorrhage has been used empirically to treat laminitis for the last 2000 years and continues to be used even today (Heymering 2010). Nevertheless, this hypothesis should be confirmed by additional studies.

DF1681B has a variable elimination half-life ranging from $0.5 \mathrm{~h}$ in rats to $10 \mathrm{~h}$ in dogs (Gorio et al. 2007); there is no information for horses presently. Thus, our protocol comprised four doses (30mg/kg) administered at 6-hour intervals. This protocol was designed to counter the developmental phase (6-30h after carbohydrate administration) when the major pro-inflammatory cytokine expression. (Leise et al. 2011, Visser \& Pollitt 2011), chemokines (Faleiros et al. 2011b), and leukocyte immigration (Faleiros et al. 2011a, Visser \& Pollitt 2011) begin in the lamellae.

Because there are no DF1681B pharmacokinetic studies in horses, it is unknown whether a different protocol would improve the therapeutic efficacy in this laminitis model. It is also unclear whether treating the horse before the oligofructose challenge would produce a different res- 
ponse. However, in rats, administered DF1681B 40 min before inducing arthritis, joint lesions were minimized 3 and $6 \mathrm{~h}$ later (Coelho et al. 2008). Intestinal lesions were ameliorated when DF1681B was administered before intestinal reperfusion in rats (Souza et al. 2004), but the best therapeutic effect following spinal cord trauma in rats required 7 days of treatment (Gorio et al. 2007). Similarly, in a murine spinal injury model, the best therapeutic results were obtained when plasma levels were maintained at $8 \mu \mathrm{g} / \mathrm{mL}$ (Gorio et al. 2007). This opens a wide avenue for further studies of varying dosing regimens in horses.

\section{CONCLUSION}

Despite the limitations of the employed model, these preliminary findings showed that DF1681B therapy prevented lamellar inflammation and dermal-epidermal junction damage in horses subjected to oligofructose-induced laminitis. Future studies will clarify the therapeutic benefits of CXCR1/2 antagonists in equine laminitis.

Acknowledgements.- The authors thank Coordenação de Aperfeiçoamento de Pessoal de Nível Superior (CAPES), Conselho Nacional de Desenvolvimento Científico e Tecnológico (CNPq), and Fundação de Amparo à Pesquisa de Minas Gerais (FAPEMIG) for their financial support. The DF1681B was donated by Dompé Pharma SpA.

\section{REFERENCES}

Ainsworth M.D., Wagner B., Franchini M., Grünig G., Erb H.N. \& Tan J.Y. 2006. Time-dependent alterations in gene expression of interleukin-8 in the bronchial epithelium of horses with recurrent airway obstruction. Am. J. Vet. Res. 67:669-677.

Belknap J.K., Giguere S., Pettigrew A., Cochran A.M., Van Eps A.W. \& Pollitt C.C. 2007. Lamellar pro-inflammatory cytokine expression patterns in laminitis at the developmental stage and at the onset of lameness: innate vs. adaptive immune response. Equine Vet J. 39:42-47.

Belknap J.K. 2010. Black walnut extract: an inflammatory model. Vet. Clin. North Am., Equine Pract. 26:95-101.

Bizzarri C., Beccari A.R., Bertini R., Cavicchia M.R., Giorgini S. \& Allegretti M. 2006. ELR+ CXC chemokines and their receptors (CXC chemokine receptor 1 and CXC chemokine receptor 2) as new therapeutic targets. Pharm. Ther. 112:139-149.

Black S.J., Lunn D.P., Yin C., Hwang M., Lenz S.D. \& Belknap J.K. 2006. Leukocyte emigration in the early stages of laminitis. Vet. Immunol. Immunopathol. 15:161-166.

Chow M.L., Winn M.E., Li H.R., April C., Wynshaw-Boris A., Fan J.B., Fu X.D., Courchesne E. \& Schork N.J. 2012. Preprocessing and quality control strategies for illumina DASL assay-based brain gene expression studies with semi-degraded samples. Front. Genet. 3:11.

Coelho F.M., Pinho V., Amaral F.A., Sachs D., Costa V.V., Rodrigues D.H., Vieira A.T., Silva T.A., Souza D.G., Bertini R., Teixeira A.L. \& Teixeira M.M. 2008. The chemokine receptors CXCR1/CXCR2 modulate antigen-induced arthritis by regulating adhesion of neutrophils to the synovial microvasculature. Arthritis Rheum. 58:2329-2337.

Faleiros R.R., Leise B.B., Westerman T., Yin C., Nuovo G.J. \& Belknap J.K. 2009a. In vivo and in vitro evidence of the involvement of CXCL1, a keratinocyte-derived chemokine, in equine laminitis. J. Vet. Intern Med. 23:1086-1096.

Faleiros R.R., Nuovo G.J. \& Belknap J.K. 2009b. Calprotectin in myeloid and epithelial cells of laminae from horses with black walnut extract-induced laminitis. J. Vet. Intern Med. 23:174-181.

Faleiros R.R., Johnson P.J., Nuovo G.J., Messer N.T., Black S.J. \& Belknap JK. 2011a. Laminar leukocyte accumulation in horses with carbohydrate overload-induced laminitis. J. Vet. Intern Med. 25:107-115.
Faleiros R.R., Leise B.S., Watts M., Johnson P.J., Black S.J. \& Belknap J.K. 2011b. Laminar chemokine mRNA concentrations in horses with carbohydrate overload-induced laminitis. Vet. Immunol. Immunopathol. 144:45-51.

Franchini M., Gill U., von Fellenberg R. \& Bracher V.D. 2000. Interleukin-8 concentration and neutrophil chemotactic activity in bronchoalveolar lavage fluid of horses with chronic obstructive pulmonary disease following exposure to hay. Am. J. Vet. Res. 61:1369-1374.

French K.R. \& Pollitt C.C. 2004. Equine laminitis: loss of hemidesmosomes in hoof secondary epidermal lamellae correlates to dose in an oligofructose induction model. Equine Vet. J. 36:230-235.

Giustizieri M.L., Mascia F., Frezzolini A., De Pità O., Chinni L.M., Giannetti A., Girolomoni G. \& Pastore S. 2001. Keratinocytes from patients with atopic dermatitis and psoriasis show a distinct chemokine production profile in response to T cell-derived cytokines. J. Allergy Clin. Immunol. 107:871-877.

Gorio A., Madaschi L., Zadra G., Marfia G., Cavalieri B., Bertini R. \& Di Giulio A.M. 2007. Reparixin, an inhibitor of CXCR2 function, attenuates inflammatory responses and promotes recovery of function after traumatic lesion to the spinal cord. J. Pharmacol. Exp. Ther. 322:972-981.

Gravena K., Sampaio R.C.L., Dias D.P.M., Canola P.A., Peiró J.R. \& Lacerda-Neto J.C. 2012. Evaluation of the integrity of horse hoof dermal and epidermal tissues collected by dorsal transmural access. J. Equine Vet. Sci. 32:858-862.

Hanly B.K., Stokes A.M., Bell A.M., Johnson J.R., Keowen M.L., Paulsen D.B., Sod G.A. \& Moore R.M. 2009. Use of serial laminar tissue collection via biopsy in conscious healthy horses. Am. J. Vet. Res. 70:697-702.

Heymering H.W. 2010. A historical perspective of laminitis. Vet. Clin. North Am., Equine Pract. 26:1-11.

Hurley D.J., Parks R.J., Reber A.J., Donovan D.C., Okinaga T., Vandenplas M.L., Peroni J.F. \& Moore J.N. 2006. Dynamic changes in circulating leukocytes during the induction of equine laminitis with black walnut extract. Vet. Immunol. Immunopathol. 15:195-206.

Leise B.S., Faleiros R.R., Watts M. Johnson P.J., Black S.J. \& Belknap J.K. 2011. Laminar inflammatory gene expression in the carbohydrate overload model of equine laminitis. Equine Vet. J. 43:54-61.

Leise B.S., Faleiros R.R., Watt M., Johnson P.J., Black S.J. \& Belknap J.K. 2012. Hindlimb laminar inflammatory response is similar to that present in forelimbs after carbohydrate overload in horses. Equine Vet. J. 44:633-639.

Lima L.R., Mendes H.M.F., Magalhães J.F., Markowicz L.C., Cavalcanti C.B., Paes Leme F.O., Teixeira M.M. \& Faleiros R.R. 2013. Avaliação clínica e hematológica de equinos submetidos ao modelo de laminite por oligofructose, tratados ou não com um agente antagonista de receptores CXCR1/2. Pesq. Vet. Bras. 33:992-998.

Loftus J.P., Black S.J., Pettigrew A., Abrahamsen E.J. \& Belknap J.K. 2007. Involving early laminar events endothelial activation in horses with black walnut-induced laminitis. Am. J. Vet. Res. 68:1205-1211.

Marsh D.R. \& Flemming J.M. 2011. Inhibition of CXCR1 and CXCR2 chemokine receptors attenuates acute inflammation, preserves gray matter and diminishes autonomic dysreflexia after spinal cord injury. Spinal Cord. 49:337-344.

Milinovich G.J., Trott D.J., Burrell P.C., Van Eps A.W., Thoefner M.B., Blackall L.L., Al Jassim R.A., Morton J.M. \& Pollitt C.C. 2006. Changes in equine hindgut bacterial populations during oligofructose-induced laminitis. Environ. Microbiol. 8:885-898.

Milinovich G.J., Klieve A.V., Pollitt C.C. \& Trott D.J. 2010. Events in the hindgut microbial during carbohydrate-induced equine laminitis. Equine Vet. Clin. 26:79-94.

Mukaida N. 2003. Pathophysiological roles of interleukin-8/CXCL8 in pulmonary diseases. Am. J. Physiol. Lung Cell Mol. Physiol. 284:L566-77

Paes Leme F.O., Bonna F.A.B., De Marval C.A., Xavier S.H.N., Santos R.L., Faleiros R.R. \& Alves G.E.S. 2010. Histopatologia das lâminas do casco de equinos com laminite aguda induzida e tratados com ketoprofeno, fenilbutazona e flunixin meglumine. Arq. Bras. Med. Vet. Zootec. 62:241-250.

Pollitt C.C. 1996. Basement membrane pathology: a feature of acute equine laminitis. Equine Vet. J. 28:38-46. 
Katz L.M. \& Bailey S.R. 2012. A review of recent advances and current hypotheses on the pathogenesis of acute laminitis. Equine Vet. J. 44:752761.

Kim H.Y., Choi J.H., Kang Y.J., Park S.Y., Choi H.C. \& Kim H.S. 2011. Reparixin, an inhibitor of CXCR1 and CXCR2 receptor activation, attenuates blood pressure and hypertension-related mediators expression in spontaneously hypertensive rats. Biol. Pharm. Bull. 341:120-127.

Rabbit F.M., Pine V., Amaral F.A., Sachs D., Costa V.V., Rodrigues D.H., Vieira A.T., Silva T.A., Souza D.G., Bertini R., Teixeira A.L. \& Teixeira M.M. 2008. The chemokine receptors CXCR1/CXCR2 modulate antigen-induced arthritis by regulating adhesion of neutrophils to the synovial microvasculature. Arthritis Rheum. 58:2329-2337.

Souza D.G., Bertini R., Vieira A.T., Cunha F.Q., Poole S., Allegretti M., Colotta F. \& Teixeira M.M. 2004. Repertaxin, a novel inhibitor of rat CXCR2 function, inhibits inflammatory responses that follow intestinal ischaemia and reperfusion injury. Br J. Pharmacol. 143:132-142.
Stewart A.J., Pettigrew A., Cochran A.M. \& Belknap J.K. 2009. Indices of inflammation in the lung and liver in the early stages of the black walnut extract model of equine laminitis. Vet. Immunol. Immunopathol. 129:254-260.

Van Eps A.W. \& Pollitt C.C. 2006. Equine laminitis induced with oligofructose. Equine Vet. J. 38:203-208.

Visser M.B. \& Pollitt C.C. 2011. Lamellar leukocyte infiltration and involvement of IL-6 during oligofructose-induced equine laminitis development. Vet. Immunol. Immunopathol. 144:120-128.

Woodman L., Sutcliffe A., Kaur D., Berry M., Bradding P., Pavord I.D. \& Brightling C.E. 2006. Chemokine concentrations and mast cell chemotactic activity in BAL fluid in patients with eosinophilic bronchitis and asthma, and in normal control subjects. Chest 130:371-378.

Zarbock A. \& Allegretti M. \& Ley K. 2008. Therapeutic inhibition of CXCR2 by Reparixin attenuates acute lung injury in mice. Brit. J. Pharmacol. 155:357-364. 